\title{
LUCA RÓKA
}

\section{Career Guidance for Disadvan- taged Students in the Hungarian Education System}

\section{INTRODUCTION}

During the 20th Century career guidance attracted more professional attention yet it was only in the latter years of the century that it became a focus point in education (Hegyi-Halmos, 2018)

A UNICEF report of 2019 states that children in education possess greater skills and abilities than children who have no education at all, even if the education is of poor quality. More developed skills and abilities make these children more prepared for employment and thus increases their potential, which is why every child should have the chance to receive an education, as laid down as a right in the 1989 UN Convention on the Rights of Children. This convention was ratified by Hungary in 1991. By law every child in Hungary has the right to study and receive equal opportunities. Hence, the state is obliged to provide career guidance and information in schools and other facilities outside schools. Thus, as these young people reach adulthood, they will be able to build a successful career and become a useful member of society.

To build a successful career it is necessary for people to identify their passion and turn it to good use in a profession. For any society, it is also important to support its members in finding their passion. Doing so will have a positive economic effect on the country. It can decrease the number of people living in extreme poverty, besides diminishing social exclusion and lessening the economic differences between people as well as regional inequalities.

Unfortunately, finding the right profession is not always easy, especially if the background of the person is questionable, in the sense that the person may have unfavourable environmental conditions, opportunities and role models inside their families. This would clearly limit their abilities and options. For these young people it is important to offer and provide services that provide further information about their opportunities, as well as counselling them about their future plans and supporting them in achieving realistic career goals. Sometimes having only one role model whom they can approach outside their family, and who can help them find the right path, is enough. (Török, 2017)

As experts such as Réka Török (2017), Tibor Borbély-Percze, Katalin Gyöngyösi, Ágnes Juhász (2013) and Tibor Borbély-Percze (2016) state, career counselling, lifelong guidance and future planning must be in focus. To this end, it is crucial for all concerned to learn the necessary competences, skills and abilities regardless of their 
family and economic background and environment. With regard to disadvantaged groups, in order to compensate for potential difficulties caused by the differences in background it is extremely important to make available opportunities and services for their support. As Aranka Varga (2012) asserts, if they do not see and understand the value of work from a young age they will not be motivated to learn anything pertaining to their job and so make it a profession. Finding and building a career is a lifelong commitment.

Although disadvantaged groups require more varied types of support, in Hungary there is a lack of appropriate service systems in public education. Solutions for career guidance may thus vary, and it is difficult to examine their impact on young people (Borbély-Percze, Gyöngyösi \& Juhász, 2013).

\section{CaReER guidance in the Hungarian EDUCATION SYSTEM}

\subsection{Career guidance in schools}

Besides families, schools have the most impact on the values and life choices of children, such as their career. Schools can motivate the students, have a positive effect on their self-esteem, teach them how to make choices independently, and offer them opportunities to accomplish their future plans. In order to plan and achieve these individual career paths it is necessary to have a suitable educational environment, the right tools and qualified experts (Varga, 2012).

Schools can also impart necessary competences and skills, such as selfknowledge, cooperation, creativity, adaptability and self-knowledge of their capacities. It is not only the teachers' job to teach these attributes, it is also the responsibility of every professional working with the students, for example social workers, school psychologists and special needs teachers (Török, 2017).

In Hungary there is no legally binding unified glossary detailing career management, and the tasks and responsibilities of the various professionals involved are unclear. In the school system future planning and career guidance only appears a year or two before the students have to choose a profession to study. It would be more useful to introduce the planning and guidance as a process, developing it over time and providing further options such as career counselling. The choice of a career is not a decision that people cannot change later, especially nowadays, but they need support to make these changes easier for them (Cserti-Szauer, 2019).

\subsection{Career guidance for students from disadvantaged groups}

Children or students from disadvantaged groups comprise a legal entity and term in Hungary. The term is used to describe children whose environment puts their development at risk, and/or whose parents or legal guardian/s finished their studies before starting vocational secondary school and/or have a low income. This study 
focuses not only on children from disadvantaged groups, according to the legal definition, but also on students with unstable backgrounds.

Students with unstable backgrounds are those who do not fall within the legal definition of disadvantaged groups but at the same time do not have a supportive family or social background. These students do not fall within the scope of the state, which is why the professionals involved have a greater responsibility in identifying and supporting them in their future plans.

Everyone needs support in career guidance, but it should always be personalised for the person or the group in the focus of these activities. The types and goals of these activities should match their personalities, knowledge and socio-demographic background, without which the guidance would be less effective.

When planning career guidance activities for students with unstable backgrounds there are some important educational tasks to perform, such as widening their everyday knowledge, nurturing realistic self-knowledge and the personal need to access future information, and teaching conflict management techniques. These activities must harmonise with the group's or person's current life situation. It is also advisable to impart this knowledge by providing them with the opportunity to gain meaningful experience (Kenderfi, 2012).

Coming from an unstable background may present a risk factor in pursuing further education. The students are often less motivated to continue their studies and find a stable job if they come from an economically poor area and if their parents did not study a profession. That lack of motivation puts them at risk of dropping out of school. In these cases, preventing the students from dropping out represents another focus of career guidance (Vágó, 2002).

\section{Methods}

The main aim of the research is to explore and illustrate the type of support that is provided as career guidance in vocational secondary schools for children from disadvantaged groups, based on the experiences of students and staff of one such school in Budapest. The research examines the efforts made by the education system, the programmes offered in school, and the personal efforts of the school staff.

The research is intended to look for the answers to the following questions:

1. What role do school staff members play in career guidance at the school?

2. What experiences and knowledge do the students have of activities and programmes that support career guidance?

3. What kind of further supporting models could be used in schools, considering the interviewed students' interests?

The study's sample group comprises students from disadvantaged groups attending vocational secondary schools, and the professionals who work with them in school. All the stages of the research (the interviews and surveys) were conducted at the same school in the Hungarian capital.

In the first stage, two semi-structured interviews were recorded based on previously written questions. The first interviewee was the school's career guidance coordinator, who expressed an opinion on the subject, not only in the school but within the whole 
education system. He is also a teacher and has his own class as a class teacher, so he could also share his experiences as a teacher. The second interviewee was the school's social worker, who is responsible for child protection services in the school, and he could share his experiences from his own professional point of view.

The surveys were used to measure the students' attitudes, experiences and knowledge of career guidance. Thirty-six students aged between 15 and 20 years participated in the research. Nineteen of the students were under 18, and studying their first profession. From these nineteen students eight came from disadvantaged groups. Seventeen of the students were older than 18. These students already had a profession and were studying for their secondary school graduation. From these seventeen students eleven came from disadvantaged groups. In the whole research study there were nineteen students in the target group and seventeen in the control group.

The questions in the surveys focus on the students' socio-demographic background, their future and their career plans, as well as their relationship with their family, besides questions that examine their career guidance. The questions about their career guidance measure how they prepared themselves for choosing a career, besides also measuring their knowledge, attitude and experience of activities and programmes that support career guidance. The students over 18 had extra questions regarding their educational background, which pertain to their career plans and the possibility of changing their originally chosen career path.

\section{FINDINGS}

\subsection{Interview 1: Career Guidance Coordinator}

The education system frequently plans events such as SzakMÁzz!, in which institutions and schools have an opportunity to introduce themselves and the vocational courses that they offer. There may also be companies and foundations that offer future opportunities in the various professions. They organise further industry-specific events with the same purpose. Épitsd a jövőd! (Build your future!) is one of these events, and focuses on professions in the construction industry. These events are helpful in the fight against students dropping out. They offer first-hand experience and information about the professions, which makes it easier to attract the attention of students who are less motivated to look for a profession or who have less opportunity to gain knowledge, similarly to students from disadvantaged groups. These events are especially attractive because they are often compulsory school trips, organised for the students. There are smaller events run by the education centre but organised by, and taking place in, the schools, such as Szakmák Éjszakája (The Night of Professions). These events prove less effective among the groups of students, with lack of interest and motivation to travel around and make an effort to gain knowledge of the professions.

The education centre has no further activities or counselling to support career guidance. There are no unified activities or methods that the schools are required to follow and use. Advice is given and general requests are responded to, but it is for the most part left to the discretion of the institutions what they choose to do, considering their options and tools. 
Since September 2019 schools have been required to provide information about their career guidance activities. This information must conform to European Union requirements although not all of them may be achievable, given the actual circumstances of the schools. The requirements include description of the support of current students in career guidance and career planning, besides providing data on sshool leavers and on the activities of school alumni.

The school where the research was conducted mostly offers future options and opportunities to support the students' careers. They organise presentations in the school where companies introduce themselves and their work, so students may establish connections in the business world. Upon request, they also post job offers on the school's notice board. The school also strongly recommends the mandatory internships at companies where the students can continue to work after their studies. However, it is difficult to find such companies if the student does not have personal connections.

A particularly sensitive issue for the school system is when students change their specialised subject. It should be a goal to make this possible between related subjects, but the education system does not allow for this. The difficulty is caused by the dual system in which, despite offering considerable experience, the annual internships may be the source of the problem, given the lack of teachers who could help the students prepare for the transition to working life.

The school's main focus is on students who are entering their last two years of secondary school, in that the school tries to make contact with them and seduce them to the school. It recommends itself and shows what it can offer, but the goal of these activities is to recruit new students and not to provide career guidance. To show potential future students what the school can offer it has four days during the school year when its door is open to the public. During these four days visitors can hear presentations about the school, visit classes and have a tour of the building. The school also participates in The Night of Professions and offers experiences in the specialisations it offers, as well as presenting itself in secondary schools, upon request, where it introduces itself and its options, and the career paths it can offer.

In the opinion of the career guidance coordinator, it would be important to increase the role of the education centre in career guidance, to offer a wider range of activities, to unify the methods employed and requests made of schools, and to give further support during the process. It is also necessary to develop more effective communication between the schools and the centre, as all the parties concerned function separately instead of working together. The centre should listen to those working in the field. Schools should establish more contacts with companies, so as to be able to offer wider options to the students for their future. He does not subscribe to the idea of preparing activities exclusively for students from disadvantaged groups, as he wishes to avoid any possible negative effects on their self-esteem.

\subsection{Interview 2: The Child Protection Referent}

With all the faults in the system the school staff have an even greater role to play in career guidance. They are not always able to prevent students from dropping out, for example if students are not sufficiently motivated or have financial problems which 
make any kind of work more important than their studies, but the staff can always try. They can help, for example, by adjusting expectations to match the students' abilities and goals.

The teachers have opportunities, even during school hours, to support students' career guidance. During class time the teacher can provide activities concerning future planning and career guidance. The class teacher can also let motivated students go to events held by the centre during school hours, or even plan class trips to go there.

Within the school, there are professionals (special needs teachers, the psychologist, the social worker), who work with the students as an interdisciplinary team. Their joint work is especially important in the school where our research was conducted, because there are many students who have behavioural disorders, or who come from disadvantaged groups and require extra, personalised support and attention.

The students do not associate these professionals with academic education and examinations, which makes it easier for them to create a safe atmosphere where the students can approach them more easily with their personal problems.

'As a teacher, during classes it would be difficult to keep the educational environment if the student shared with you all their sorrows and sadness' (The child protection referent)

In their situation the lack of everyday contact can make it difficult to develop a trusting relationship. To overcome this difficulty, since last year, they have held 15-30 minute meetings with every student at the beginning of the year, in which they have a friendly chat to introduce themselves and their work and assess the students' background. This routine will make their work easier later. Thus, the students will know who they may approach, and whenever needed, the professionals can offer help or support them faster with this knowledge. These professionals also introduce themselves to the whole class and organise activities for them during the year. In addition, they have another way of maintaining contact with the students. Ten years ago, they initiated a project and established a communal area in the school where students can play table football, billiards and other games such as chess, or just have a chat. It provides these non-teaching staff members with an opportunity to build a relationship with the teenagers in a comfortable way and identify those who need extra attention. These professionals workers do not work directly in career guidance, but if there is a sign in the students' behaviour that someone is in need of counselling because their specialised subject is not ideal for them, they help solve the problem and find the career path that is most suitable for the student.

'Two or three years ago there was a girl who came from another school in the middle of the year. She had a behavioural disorder, which was the reason why she had to change schools, so the school psychologist and I invited her for a little chat, just the three of us. It soon transpired that the profession she was studying was not one she was interested in. She wanted to go to the same school where her sibling had planned to go. During the year we had a meeting with her and her parents and in the end she expressed her wish to her parents as well. Luckily, they were cooperative and supportive. She could start the following next year at the school where she wanted to go.' (The child protection referent) 
Preventing students from dropping out is one of the main responsibilities of these professional helpers. Whenever there is a student at risk of dropping out they organise meetings with the teenager concerned, his or her parents, because usually the parents have the most effect on the students' motivation, although the media can also have a (mostly negative) impact, and the teachers who work with the student regularly. If any of these people do not cooperate fully, they are fighting a losing battle. Another factor can be a negative peer effect that can cause drop-out. To prevent this, they hold mediation meetings between the parties and organise class activities. These activities usually last between four and ten sessions and may focus on conflict management, crime or the prevention of bullying. Adverse environmental conditions may also be a cause of students dropping out, so the staff try to create a student-friendly environment in the school to motivate the young people to stay. They work on nurturing a beneficial school atmosphere and a strong class spirit, providing team building activities, and giving positive feedback.

The child protection referent's opinion is that they could work more effectively if the students had met them and become familiar with their role at a younger age, maybe in primary school or even nursery. Early encounters would accustom the children to their presence and encourage them to ask for their help.

\subsection{Surveys}

Students in both the control and the target groups mostly identified completing the same three lowest levels of education as future goals, to enter a manual profession, to graduate from secondary school, or to attend professional training after graduating from vocational secondary school: but in different proportions. Any similarities possibly derived from the type of school, while the differences are that the students from disadvantaged groups more frequently chose the lower education levels as opposed to the control group who chose higher goals in education. Seven students from the target group wanted to enter a manual profession, six would also aimed to graduate from secondary school, and two aimed to attend further professional training after graduation. This contrasted with the control group, of whom three chose a manual profession, seven aimed for secondary school graduation, and five intended to pursue further professional training after graduation.

The desired highest level of education is partly explained by the students' family backgrounds. Every member of the control group said that their parents supported them in their studies while in the target group four students said that they were not supported in the same way. It is noteworthy that two students said that although their parents supported them in their studies they had been financially self-sufficient since they had turned sixteen. In their case an unstable financial background and the need to work may put their further studies and opportunities at risk.

The family affects not only the students' motivation and goals but also the career choices they make. Four students from the target group and seven from the control group, all under the age of 18 , chose a profession also held by another family member. Other than the parents there were other persons to whom the students would turn for help in career guidance. 
Table 1. Who affects the students' career choices? (edited by the author)

\begin{tabular}{|l|c|c|c|c|}
\cline { 2 - 5 } \multicolumn{1}{c|}{} & \multicolumn{2}{c|}{ Aged under 18 } & \multicolumn{2}{c|}{ Aged 18 and over } \\
\cline { 2 - 5 } \multicolumn{1}{c|}{} & $\begin{array}{c}\text { Target } \\
\text { group } \\
\text { (8 persons) }\end{array}$ & $\begin{array}{c}\text { Control } \\
\text { group } \\
\text { (11 persons) }\end{array}$ & $\begin{array}{c}\text { Target } \\
\text { group } \\
\text { (11 persons) }\end{array}$ & $\begin{array}{c}\text { Control } \\
\text { group } \\
\text { (6 persons) }\end{array}$ \\
\hline Parents & 7 & 11 & 6 & 5 \\
\hline Siblings & 4 & 1 & 3 & 1 \\
\hline Others & 4 & 1 & 5 & 2 \\
\hline Teachers & 3 & 0 & 0 & 2 \\
\hline School psychologist & 0 & 0 & 0 & 0 \\
\hline Special needs teacher & 0 & 0 & 0 & 0 \\
\hline Social worker & 0 & 0 & 0 & 0 \\
\hline
\end{tabular}

Unfortunately, the least likely scenario is that they would approach the professional helpers (psychologists, special needs teachers and/or social workers), which confirms that they are not sufficiently familiar with this option and the professionals' competences, or not confident enough to ask them for counselling.

'Their trust is easily breakable, and a must to have in our job' (The child protection referent)

A trusting relationship is critical for students in choosing who to approach. More students in the target group chose 'others' as an answer to whom would they approach than students in the control group, probably because of the lower degree of support they received from their parents. By 'others' they usually identified friends, relatives and acquaintances, yet some identified the media as an effect on their choice. In the target group, another popular answer was that of 'siblings'. An interesting finding is that the importance of the teacher's role was opposite in the two age groups (under or over eighteen). Among those under eighteen, three members of the target group but none from the control group would ask for their advice, while among those over eighteen none of the target group and two of the control group thought teachers influenced their career choice.

Ideally, choosing a career does not only involve making a choice, rather, it is an entire planning process until they are able to make the right decision for a successful future that is suitable for them. There are four steps to take before coming to a decision: setting future goals, assessing their abilities and interests, collecting information and planning their future career. None of the participants took all four of these steps. 
Table 2. Steps before choosing a profession (edited by the author)

\begin{tabular}{|l|c|c|}
\cline { 2 - 3 } \multicolumn{1}{c|}{} & \multicolumn{1}{c|}{$\begin{array}{c}\text { Target group } \\
\text { (19 persons) }\end{array}$} & $\begin{array}{c}\text { Control group } \\
\text { (17 persons) }\end{array}$ \\
\hline Setting future goals & 9 & 12 \\
\hline Measuring abilities, interests & 7 & 5 \\
\hline Collecting information & 4 & 7 \\
\hline Planning their career & 3 & 6 \\
\hline
\end{tabular}

Most of the students set future goals during the process, the number of these students being especially outstanding in the control group with twelve of its students. Fewer students from the control group measured their abilities and interests than from the target group, only five as opposed to seven, their high level of self-knowledge rendering this step unnecessary. In the target group nearly twice as many teenagers assessed their abilities and interests than either those who collected information or those who planned their career, which may indicate that most of them probably did not give much conscious thought to the decision. Although students from disadvantaged groups appeared less conscious of the four steps they have more information about the programmes and options that are potentially helpful in career guidance, such as websites, the school psychologist and the Bridge programme (Híd-program), which, until January 2020, was a state programme intended to help students continuing their studies in vocational secondary school after experiencing difficulties at secondary school.

Table 3. Career guidance services of which the students have heard (edited by the author)

\begin{tabular}{|l|c|c|}
\cline { 2 - 3 } \multicolumn{1}{c|}{} & $\begin{array}{c}\text { Target group } \\
\text { (19 persons) }\end{array}$ & $\begin{array}{c}\text { Control group } \\
\text { (17 persons) }\end{array}$ \\
\hline Websites & 5 & 7 \\
\hline The Bridge programme & 4 & 4 \\
\hline Educational Services & 3 & 0 \\
\hline Mentor programmes & 2 & 0 \\
\hline School psychologist & 2 & 5 \\
\hline Study-halls & 2 & 1 \\
\hline Art-ravaló & 1 & 1 \\
\hline Other & 0 & 0 \\
\hline
\end{tabular}

These were the three most well-known services in the control group. Only a few said they knew about study-halls outside school and an alternative art programme called Art-ravaló. By way of contrast, all the programmes were chosen at least by one person in the target group. This indicates that students from disadvantaged groups, probably because of their social demographic background, may have more information about these services but it is not enough, and it does not include all the programmes and 
activities. Hence, they will not be able to choose the career most suitable for them, which can have a negative effect on their motivation to make use of these services.

The data also shows that although the target group's knowledge is more extensive, the students are not inclined to use the services if they are not mandatory or organised by the school.

Table 4. Career guidance services used by the students (edited by the author)

\begin{tabular}{|l|c|c|}
\cline { 2 - 3 } \multicolumn{1}{c|}{} & $\begin{array}{c}\text { Target group } \\
\text { (19 persons) }\end{array}$ & $\begin{array}{c}\text { Control group } \\
\text { (17 persons) }\end{array}$ \\
\hline Centre-organised events & 14 & 12 \\
\hline Activities in class & 6 & 5 \\
\hline The Bridge programme & 2 & 1 \\
\hline Educational Services & 1 & 0 \\
\hline Mentor programmes & 1 & 0 \\
\hline School psychologist & 0 & 1 \\
\hline Study-halls & 0 & 0 \\
\hline Art-ravaló & 0 & 1 \\
\hline Other & 0 & 0 \\
\hline
\end{tabular}

Most of the students from both groups had attended a career guidance event organised by the education centre and approximately a third of both groups had participated in at least one career guidance activity during class time. A small number of students participated in other activities but there were no significant differences between the two groups.

The students were given an opportunity to write down what other type of career guidance activities would they like to participate in. All their ideas were experiencefocused and specialised in their professional subjects. They also relished those that took place on school premises, such as class time activities or The Night of the Professions.

For those over eighteen there was one extra question focusing on the possibility of changing their profession. Four students from the target group and three from the control group mentioned plans to change their career path entirely or at least continue to study related professions. Three of those who planned to change said that the reason was that their original profession was not suitable for them, which means that the career choice they made was unsuccessful and they did not receive adequate support in correcting it in time. One was unable to find a job in their profession and three only wished to have more stability and options by being able to do more types of work. This last reason was extremely popular among the target group. 


\section{CONCLUSIONS}

The following conclusions are made in full knowledge of the study's limitations. The research does not claim to be representative, as it was conducted to reveal the experiences of one school in career guidance. The methods used were not standardised. The conclusions and suggestions are based on the school's experiences and therefore are not applicable for the whole education system without further research being initiated.

It was revealed that the education centres provide no unified services or activities for students from disadvantaged groups to help their career planning and career guidance. There are no general activities and services either. Secondary schools mostly focus on recruiting new students, but while introducing the courses they offer, they also help with career guidance. It is, for the most part, the responsibility of the professionals to support the student's career guidance as well as they can, by organising activities. As long as the system neither unifies their methods and activities by law, nor supports the professionals with the necessary tools and training, improvement is not a realistic expectation. Expectations of the schools should be harmonised among all schools in order to make it successful.

The surveys showed that the family has considerable influence on the children's career guidance and career choices, but in disadvantaged groups it is often less supportive regarding education. The target group needs compensation for that with activities and counselling with someone they trust, otherwise they will not be motivated to participate in them. The need for a trusting relationship also applies to the teachers, as without that they cannot influence and motivate students to continue their studies. Teachers also represent a connection between students and the career guidance options. They must be well-informed about the available services and options, so as to be able to offer them to the students.

It is necessary to improve the career guidance system in education, which should start at a young age, possibly in the nursery, and continue on every level within the education system. For it to work, it would need to have unified methods and tools, the teachers should be trained to deliver it, and there should be constant communication between the education centres and the schools. It would also be useful to create a website that contains all activities, programmes, and other options for career counselling, with the necessary information such as what they can offer, what they do, and how to contact them.

While career guidance does not have a system such as the one described, designating a greater role to the professional helpers could also be effective. The special needs teachers can motivate the students, make them feel successful and improve their abilities and skills. The social workers can offer the students social support and make them more competent in using their social skills. The school psychologists can consult with the students about their difficulties and uncertainties. 


\section{SUMMARY}

The attitudes towards career guidance and future planning have changed during the last hundred years. Providing support in it has become an important goal worldwide. However, Hungary does not yet have a unified support system for career guidance. Without adequate methods and tools teachers need to be creative in providing effective support. Teachers and professional helpers should rely on each other and share their methods and information in order to support those who do not have enough social support or a sufficiently beneficial environmental background to find their career path.

\section{References}

Borbély-Percze T. B., Gyöngyösi K. \& Juhász Á. (2013). Az életút támogató pályaorientáció a köznevelésben I. Új Pedagógiai Szemle, 63(5-6), 32-49. https://folyoiratok.oh.gov.hu/ uj-pedagogiai-szemle/az-eletut-tamogato-palyaorientacio-a-koznevelesben-1-resz-0

Borbély-Percze T. B. (2016). Szakképzés és pályaorientáció - tévutak és lehetőségek. Educatio, 1, 59-69. http://epa.oszk.hu/01500/01551/00095/pdf/EPA01551_educatio_2016_1_059-069.pdf [Accessed: 08. 10. 2020.]

Cserti-Szauer Cs. (2019). A sajátos nevelési igényű fiatalok számára nyújtott, az egész életutat támogató pályaorientációs szolgáltatások. In Mesterházi Zs. \& Szekeres Á. (eds), A nehezen tanuló gyermekek iskolai nevelése (pp 610-624). Budapest: ELTE Bárczi Gusztáv Gyógypedagógiai Kar.

Hegyi-Halmos N. (2018). Mi a pálya? Az iskolai pályaorientáció szerepe és gyakorlata a hazai gimnáziumokban. Budapest: ELTE Eötvös Kiadó.

Kenderfi M. (2012). Hátrányos helyzetű fiatalok pályaérettségének fejlesztését célzó pályaorientációs csoportfoglalkozások tapasztalatai. In Szilágy K. (ed.), A pályaorientáció szerepe a társadalmi integrációban (pp 83-97). Budapest: ELTE TÁTK.

Török R. (2017). A pályadöntések mesterei. Budapest: Print \& Pixel House Kiadó.

UNICEF. (2019). Convention on the rights of children. New York: United Nations Children's Fund (UNICEF). https://www.unicef.org/reports/convention-rights-child-crossroads-2019 [Accessed: 08. 10. 2020.]

Varga A. (2012). Metszéspontok. Gyermekvédelem és iskola. Pécs: PTE BTK Oktatáskutató központ Virágmandula KFT.

Vágó I. (2002). Tanulói továbbhaladás hátrányos helyzetben. Iskolakultúra, 12(3), 76-97. http:// real.mtak.hu/60918/1/EPA00011_iskolakultura_2002_03_076-097.pdf [Accessed: 08. 10. 2020.]

\section{Online Pages}

UNICEF: A gyermekjogi egyezményröl. https://unicef.hu/gyermekjogok/gyermekjogi-egyezmenyrol/ [Accessed: 08. 10. 2020.]

\section{Laws}

1991 évi LXIV. a gyermekek jogairól szóló törvény 28. cikk 1. bekezdés

2011. évi CXC. törvény a nemzeti köznevelésről, rövidítése: Köznevelési Törvény 